\title{
THE EFFECT OF SUPERABSORBENT POLYMER APPLICATION ON YIELDING OF WINTER WHEAT (TRITICUM AESTIVUM L.)
}

\author{
Jerzy Grabiński, Marta Wyzińska \\ Institute of Soil Science and Plant Cultivation - State Research Institute, Poland \\ jurek@iung.pulawy.pl
}

\begin{abstract}
Superabsorbents are hydrophilic polymers that can absorb large amounts of water. These studies show that the use of superabsorbent may significantly reduce the negative effects of drought stress on plants. However, their use in the field cultivation has so far been minimal. The price of hydrogels has recently decreased significantly. This was the reason for starting research described in this work, in which the experimental plant was the winter wheat cultivar 'Lucullus' - the cereal which is the most intensively cultivated in Poland. The field experiment was conducted in the years of 2014 - 2016, in the Agricultural Experimental Station (AES) in Osiny, Poland, in 4 repetitions. TerrahydrogelAqua was evaluated in the following doses: 1) control without hydrogel, 2) 10, 3) 20 and 4) $30 \mathrm{~kg} \cdot \mathrm{ha}^{-1}$. Before harvesting, the plant samples were taken to determine the yield structure elements. After harvesting, grain yield at $15 \%$ moisture content was determined. The influence of hydrogel on winter wheat grain yield varied in individual years. On average, the yield of wheat grain from the treatment with a dose of $30 \mathrm{~kg} \cdot \mathrm{ha}^{-1}$ of hydrogel was significantly higher than from the control treatment or the treatment with a dose of $10 \mathrm{~kg} \cdot \mathrm{ha}^{-1}$ of hydrogel. The mean values of yield structure features, i. e. ear grain yield and weight of thousand grain were the highest at the dose of $30 \mathrm{~kg} \cdot \mathrm{ha}^{-1}$ of hydrogel. The effect of hydrogel on the average number of plants and ears per unit area and on the number of grains per ear was not found. Key words: winter wheat, superabsorbent, hydrogel, yield.
\end{abstract}

\section{Introduction}

Superabsorbents, also known as hydrogels, are hydrophilic polymers that can absorb large amounts of water (Junping, An, \& Aigin, 2006). In the dry state, they have the form of compact clusters, while under the influence of water, their functional groups become solvent and dissociate. Cations get separated and negative charges connected with polymer chains repel under the influence of electrostatic forces. This loosens the polymer and results in the possibility of water absorption. This process ends when the polymer chains are maximally elongated (Bereś \& Kałędowska, 1992). One gram of hydrogel can absorb up to $1000 \mathrm{~g}$ of water, although according to Dąbrowska \& Lejcuś (2012), absorbents with an absorbent capacity greater than $600 \mathrm{~g} \cdot 1 \mathrm{~g}^{-1}$ are not used in practice.

The most commonly used hydrogels are the ones formed on the basis of polyacrylamide, polyacrylic acid, polymethyl acid and the derivatives of these compounds.

Superabsorbents have already started to be used in land reclamation (Bereś \& Kołędowska, 1992) or forestry (Dąbrowska \& Lejcuś, 2012). A number of studies have also been carried out on the effects of superabsorbents on the soil (Lejcuś et al., 2006). In this case, these compounds are treated as moisture buffers. Studies have shown that by retaining water, superabsorbents can limit the leaching of nutrients and plant protection products to the deeper layers of the soil profile. Water retained by superabsorbents can be easily utilized as the binding forces of the water in the superabsorbent are lower than the suction force of roots. According to Lejcuś et al. (2006), the utilisation rate exceeds $90 \%$.
Despite many studies, it is not yet clear to what extent superabsorbents affect the soil structure (de Boodt, 1993). However, some authors believe that hydrogeogels may cause the soil to become loosened due to repeated swelling and shrinking. Thus, they can have a positive effect on soil aeration under water excess (Nowosielski, 1996). According to Helia, ElAmir, \& Shawky (1992), as a result of hydrogel action, micropores are interrupted and evapotranspiration decreases. However, interrupting the micropores does not affect the porosity of the soil, and therefore anaerobic root rot does not occur. This suggests that superabsorbents can play a role not only in light soils but also in heavy soils, where water scarcity is rare.

The absorption of water in the superabsorbent occurs within a very wide range of $\mathrm{pH}$ from 4 to 11 , so soil acidity is not a limiting factor for effective action. Water hardness has some influence on water absorption by the hydrogels. With increased hardness, this absorption is lower. But even in the case of very hard water, i. e. exceeding $700 \mathrm{mg} \mathrm{CaCO}_{3}$, the absorption of water by hydrogels does not stop (Malisz \& Kałędowska, 1994).

The improvement of water and air relations by superabsorbents causes the treatment with these substances show better root formation, faster development and growth of plants, and thus a higher drought resistance of vegetables (Jabłońska-Ceglarek \& Cholewiński, 1998), grasses (Sady \& Domagała, 1994), tobacco (Kościk \& Kowalczyk-Juśko, 1998), and trees (Lejcuś et al., 2006).

Most frequently it is proposed to use polymers by mixing them with the soil (Lejcuś et al., 2008). A positive effect of hydrogels on plants is generally 
not questioned in literature. However, their use in the field cultivation has so far been minimal. The price of hydrogels has recently decreased significantly. According to the data from 2011, $1 \mathrm{~kg}$ of hydrogel can be bought for about USD 5 per kilogram (Mao et al., 2011). If we consider that the dose per $1 \mathrm{ha}$, as proposed by producers, is between 10 and $15 \mathrm{~kg} \mathrm{ha}^{-1}$, that is to say, the cost of its application per 1 ha does not exceed the cost of using good quality fungicide in cereal sowing, and is therefore relatively low. It should be added that in Poland, field crop producers (especially of quality wheat) are starting to use superabsorbents by importing them directly from China.

To sum up, knowledge of superabsorbents is relatively broad, but the amount of information on the effects of using these substances in field crops, is low.

The aim of the study was to determine the influence of superabsorbent on the yield and yield component traits of the structure of winter wheat yield.

\section{Materials and Methods}

The field experiment was carried out in the years of 2014-2016, in AES Osiny ( $\left.51^{\circ} 27^{\prime} \mathrm{N} 22^{\circ} 2^{\prime} \mathrm{E}\right)$, the Lubelskie voivodeship, Poland, in the crossed subblock design, in 4 replications. TerrahydrogelAqua (crosslinked acrylic, potassium polymer) evaluated during the experiment was assessed at the following rates: 1) control - without hydrogel, 2) 10, 3) 20 and 4) $30 \mathrm{~kg} \cdot \mathrm{ha}^{-1}$. The size of the plot at the set-up and harvesting was $100.0 \mathrm{~m}^{2}$. The experiment was carried out on the Albic Podzols soil, sandy loam, suitable to winter wheat production. The experimental plant was a winter form of wheat cultivar 'Lucullus'. The sowing date and all agronomic treatments were applied according to the recommendations specified in the latest instructions issued by the Institute of Soil Science and Plant Cultivation State Research Institute for the respective species. During the vegetation period, dates of the plant development stages were noted. Prior to the harvest, samples of plants were taken in order to determine the elements of yield structure: number of plants and ears per area unit, grain yield per ear, weight of thousand grains, and the number of grains per ear. Harvesting was carried out at full maturity stage (BBCH 97). The yield has been calculated at $15 \%$ moisture content.

The experiment was conducted using annually the hydrogel described in Table 1.

The results were statistically analyzed using a one-way ANOVA and the Statgraphics Centurion XVI computer program. Significance of differences between means was evaluated using the Tukey test at the level of significance $\mathrm{p}=0.05$.

\section{Results and Discussion}

Data from a meteorological station located in the AES in Osiny, where the research was conducted, were used to describe the weather conditions in subsequent

Characteristics of TerrahydrogelAqua (crosslinked acrylic, potassium polymer)

\begin{tabular}{|l|l|}
\hline moisture $(\%)$ & $6-10$ \\
\hline degree of absorption of distilled water & $350-550 \mathrm{~g} \cdot 1 \mathrm{~g}^{-1}$ of gel \\
\hline degree of absorption of brine & $40-70 \mathrm{~g} \cdot 1 \mathrm{~g}^{-1}$ of gel \\
\hline speed of absorption & $0.5-2 \mathrm{~h}$ \\
\hline Granulation & $20-40$ mesh \\
\hline Biodegradation & $3-5$ years \\
\hline $\mathrm{pH}$ & $6-8$ \\
\hline Commercial form & Granulated \\
\hline registration & REACH \\
\hline
\end{tabular}

Soil nutritional status $\left(\mathrm{mg} \cdot 100 \mathrm{~g}^{-1}\right)$ and $\mathrm{pH}$ in individual years of the study

\begin{tabular}{|l|c|c|c|c|}
\hline \multirow{2}{*}{\begin{tabular}{c}
\multirow{2}{*}{ Year } \\
\multirow{2}{*}{$\mathrm{pH}$}
\end{tabular}} & \multicolumn{3}{|c|}{ Soil nutritional status } \\
\cline { 3 - 5 } & & $\mathrm{P}_{2} \mathrm{O}_{5}$ & $\mathrm{~K}_{2} \mathrm{O}$ & $\mathrm{Mg}$ \\
\hline 2014 & 6.59 & 17.8 & 16.9 & 2.1 \\
\hline 2015 & 6.02 & 15.8 & 12.7 & 3.4 \\
\hline 2016 & 6.44 & 21.9 & 14.5 & 4.5 \\
\hline
\end{tabular}


Meteorological conditions in individual growing seasons (2014 - 2016)

\begin{tabular}{|c|c|c|c|c|}
\hline \multirow{2}{*}{ Month } & \multicolumn{4}{|c|}{ Year } \\
\hline & $2013 / 2014$ & $2014 / 2015$ & $2015 / 2016$ & Long-term average \\
\hline \multicolumn{5}{|c|}{ Temperature $\left({ }^{\circ} \mathrm{C}\right)$} \\
\hline September & 14.5 & 15.1 & 15.3 & 13.3 \\
\hline October & 7.2 & 10.1 & 7.3 & 8.0 \\
\hline November & 5.2 & 4.9 & 5.2 & 2.8 \\
\hline December & 4.1 & 0.6 & 4.0 & -1.3 \\
\hline January & -3.5 & 1.2 & -3.3 & -3.3 \\
\hline February & 3.6 & 1.0 & 3.7 & -2.3 \\
\hline March & 4.0 & 4.1 & 4.3 & 1.6 \\
\hline April & 9.2 & 8.6 & 9.6 & 7.8 \\
\hline May & 14.7 & 13.9 & 15.6 & 13.5 \\
\hline June & 18.9 & 17.9 & 19.8 & 16.8 \\
\hline July & 19.4 & 20.4 & 20.1 & 18.5 \\
\hline \multicolumn{5}{|c|}{ Rainfall (mm) } \\
\hline September & 41 & 12 & 118 & 51 \\
\hline October & 5 & 22 & 27 & 43 \\
\hline November & 49 & 21 & 38 & 39 \\
\hline December & 14 & 36 & 27 & 37 \\
\hline January & 49 & 43 & 33 & 31 \\
\hline February & 24 & 5 & 64.5 & 30 \\
\hline March & 42 & 21 & 53 & 30 \\
\hline April & 73 & 28 & 38.4 & 40 \\
\hline May & 189 & 108 & 72.2 & 57 \\
\hline June & 121 & 32 & 27.9 & 70 \\
\hline July & 63 & 55 & 86.6 & 84 \\
\hline
\end{tabular}

growing seasons. They varied significantly over the years. In the first year of the study (Table 3) there was a relatively large total rainfall and relatively favorable rainfall distribution, especially in the spring growing period. In the second year of the study, the weather conditions were less favorable for wheat development - the rainfall was significantly lower than usually in May and July during the period of intensive plant growth (May-BBCH 32-65) and ripening (July-BBCH 83-89). On the other hand, in the 2015/2016 research season meteorological conditions were not favorable as well, due to much lower precipitation in May and June, when wheat plants underwent flowering (BBCH 61-69) and grainfilling stages (BBCH 71-77) (Table 3).

In each year of the study, winter wheat grain yield significantly depended on the dose of superabsorbent. In 2014, significantly higher yields of wheat were obtained from the treatment with the highest dose of hydrogel compared to the treatments with the lowest dose of hydrogel and the control. In the following year of the study (2015), the highest winter wheat grain yield was obtained using hydrogel in the amount of $30 \mathrm{~kg} \cdot \mathrm{ha}^{-1}$, whereas a significantly lower yield was obtained from the control object and with the lowest dose of hydrogel $\left(10 \mathrm{~kg} \cdot \mathrm{ha}^{-1}\right)$. On average from three years of research, wheat yielded the highest at the treatment with a dose of $30 \mathrm{~kg} \cdot \mathrm{ha}^{-1}$ of hydrogel, while significantly lower at the control treatment and one with a dose of $10 \mathrm{~kg} \cdot \mathrm{ha}^{-1}$ (Table 4).

The analysis of the yield structure from this experiment showed that the use of hydrogel did not have a significant impact on the number of plants and ears per area unit (Fig. 1, Fig. 2), while it had a positive effect on the grain yield per ear. In the years 2014 and 2015, the highest value of this trait was found in the treatments where hydrogel was used at the highest dose, while significantly lower in the control treatment $\left(0 \mathrm{~kg} \cdot \mathrm{ha}^{-1}\right)$. In the last year of the study, no statistically significant differences were found between the 
Yield of winter wheat $\left(\mathrm{t} \cdot \mathrm{ha}^{-1}\right)$ depending on superabsorbent dose in Osiny

Table 4

\begin{tabular}{|l|c|c|c|c|}
\hline \multirow{2}{*}{$\begin{array}{c}\text { Dose of superabsorbent } \\
\left(\mathrm{kg} \cdot \mathrm{ha}^{-1}\right)\end{array}$} & \multicolumn{3}{|c|}{ Year } & \multirow{2}{*}{ Mean } \\
\cline { 2 - 5 } & 2014 & 2015 & 2016 & 8.09 \\
\hline 0 & 8.72 & 7.34 & 8.22 & 8.03 \\
\hline 10 & 9.42 & 6.43 & 8.25 & 8.67 \\
\hline 20 & 9.48 & 7.57 & 8.96 & 9.29 \\
\hline 30 & 9.46 & 9.56 & 8.86 & 1.156 \\
\hline LSD $_{0.05}$ & 0.715 & 2.128 & 0.718 & \\
\hline
\end{tabular}

treatments in terms of ear grain yield, although the tendency of significantly lower ear grain yield from the ears in the control treatments and ones treated with the lowest dose of $10 \mathrm{~kg}$ of hydrogel was quite clear
(Table 4). On average, in the three years of the study, the grain yield from ears treated with hydrogel applied at a dose of $30 \mathrm{~kg} \cdot \mathrm{ha}^{-1}$ was significantly higher than in the control (without hydrogel).

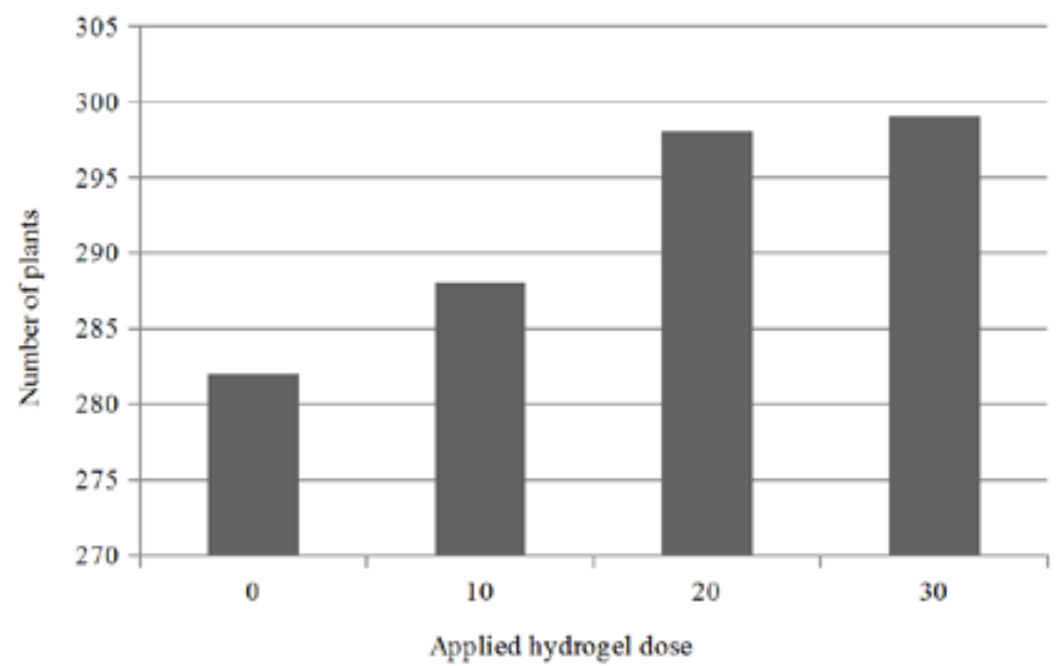

Figure 1. Number of plants per $1 \mathrm{~m}^{2}$ in Osiny depending on superabsorbent dose (mean in the years $2014-2016)(\mathrm{p}>0.05)$.

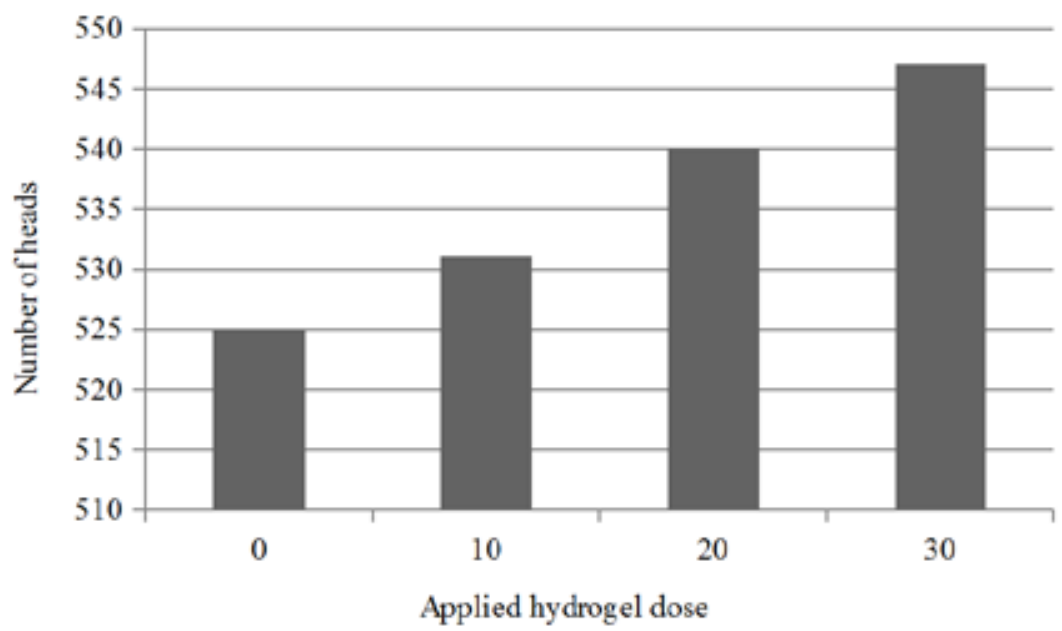

Figure 2. Number of head per $1 \mathrm{~m}^{2}$ in Osiny depending on superabsorbent dose (mean in the years $2014-2016)(\mathrm{p}>0.05)$. 
Yield of grain per head (g) depending on superabsorbent dose in Osiny

\begin{tabular}{|l|c|c|c|c|}
\hline \multirow{2}{*}{$\begin{array}{c}\text { Dose of superabsorbent } \\
\left(\mathrm{kg} \cdot \mathrm{ha}^{-1}\right)\end{array}$} & \multicolumn{3}{|c|}{ Year } & \multirow{2}{*}{ Mean } \\
\cline { 2 - 5 } & 2014 & 2015 & 2016 & 1.567 \\
\hline 0 & 1.62 & 1.56 & 1.52 & 1.597 \\
\hline 10 & 1.69 & 1.56 & 1.54 & 1.673 \\
\hline 30 & 1.71 & 1.67 & 1.64 & 1.763 \\
\hline $\mathrm{LSD}_{0.05}$ & 1.74 & 1.89 & 1.66 & 0.183 \\
\hline
\end{tabular}

$*-\mathrm{p}>0.05$

Table 6

Weight of thousand grain (g) depending on superabsorbent dose in Osiny

\begin{tabular}{|l|l|l|l|l|}
\hline \multirow{2}{*}{$\begin{array}{c}\text { Dose of superabsorbent } \\
\left(\mathrm{kg} \cdot \mathrm{ha}^{-1}\right)\end{array}$} & \multicolumn{3}{|c|}{ Year } & \multirow{2}{*}{ Mean } \\
\cline { 2 - 5 } & 2014 & 2015 & 2016 & 43.16 \\
\hline 0 & 42.67 & 44.67 & 42.13 & 43.61 \\
\hline 10 & 43.15 & 45.57 & 42.11 & 44.44 \\
\hline 30 & 43.43 & 45.56 & 44.34 & 44.90 \\
\hline LSD $_{0.05}$ & 44.19 & 46.27 & 44.23 & 1.466 \\
\hline
\end{tabular}

$*-\mathrm{p}>0.05$

A trait which define the grain filling degree is the weight of thousand grains (WTG). The highest WTG in 2014 was achieved by wheat grain from the treatments where hydrogel was applied at a dose of $30 \mathrm{~kg} \cdot \mathrm{ha}^{-1}$, while significantly lower from the control treatments. In the subsequent year of the study, the value of this trait did not significantly depend on the dose of hydrogel, however, a tendency to a higher value of the WTG was noted in the variants where superabsorbent was applied. In 2016, WTG was significantly higher in the treatments with the doses 20 and $30 \mathrm{~kg}$ of hydrogel per 1 ha, compared to the treatments with the lowest dose or the control. The mean of three years of the above trait of yield structure achieved the highest value in the treatment with a dose of $30 \mathrm{~kg} \cdot \mathrm{ha}^{-1}$ and decreased as the dose decreased, whereas statistically significant differences were found for the highest dose and the control treatment (Table 6).

A significant influence of hydrogel on the number of grains per ear was observed in the first two years of the study. However, in the first one, the value of this trait in treatments where hydrogel was used (regardless of a dose) was similar, whereas in the control, it was significantly lower. In the second

\section{Grain number per head depending on superabsorbent dose in Osiny}

Table 7

\begin{tabular}{|l|l|l|l|l|}
\hline \multirow{2}{*}{$\begin{array}{c}\text { Dose of superabsorbent } \\
\left(\mathrm{kg} \cdot \mathrm{ha}^{-1}\right)\end{array}$} & \multicolumn{3}{|c|}{ Year } & \multirow{2}{*}{ Mean } \\
\cline { 2 - 5 } & 2014 & 2015 & 2016 & 35.18 \\
\hline 0 & 36.63 & 32.82 & 36.08 & 36.66 \\
\hline 10 & 39.17 & 34.23 & 36.57 & 37.67 \\
\hline 20 & 39.37 & 36.65 & 36.99 & 38.80 \\
\hline 30 & 39.38 & 40.85 & 36.17 & n.s. \\
\hline $\mathrm{LSD}_{0.05}$ & 2.126 & 1.328 & n.s.* & \\
\hline
\end{tabular}

$*-\mathrm{p}>0.05$ 
year of the study, the differences of this feature were relatively large. As the dose of hydrogel decreased, the number of grains per ear decreased significantly as well. The difference in the number of grains in the treatment with the highest dose and the control was as high as 8. In 2016, no differences in the amount of grains per ear were found. On average, the number of grains per ear decreased markedly over three years together with the decrease of the hydrogel dose, and it was the lowest in the control treatment. However, it was not a statistically significant difference (Table 7).

A certain reference to presented on studies could be research works, in which the effect of various levels of drought stress on cereals was measured. Usually in these papers the increasing of available water influences the increase of thousand kernels of grain and grain number per head (Kilic \& Yagbasanlar, 2010), as in this paper in the objects with larger doses of superabsorbent.

Due to the lack of literature on the use of superabsorbents in field crops, particularly in cereals, our studies were of recognition nature. They showed that the use of superabsorbent may lead to significant yield increases, which gives grounds for making a hypothesis about the necessity to continue these studies under other soil or weather conditions. In subsequent years of the study, there were some rain shortages, but these were not very large. It seems that if they had been larger, the effect of superabsorbent could have been more significant. It should also be noted that the doses used were in a relatively narrow range in order to perform a realistic assessment of the possibility of using the superabsorbent, taking into account its current price. It cannot be excluded that if the price falls, then it will become justified to examine the effects of higher doses than those included in this work.

\section{Conclusions}

1. The effect of hydrogel on winter wheat yield varied throughout the years. A stronger positive impact was observed in years with bigger rainfall deficit.

2. On average for three years, the application of the superabsorbent at a dose of $30 \mathrm{~kg} \cdot \mathrm{ha}^{-1}$ resulted in a significant increase in wheat grain yield.

3. The use of hydrogel did not affect the number of plants and ears of winter wheat per area unit but, in general, it significantly increased the number of grains per ear and the weight of 1000 grains, and thus the grain yield per ear.

\section{References}

1. Bereś, J., \& Kałędkowska, M. (1992). Superabsorbenty (Superabsorbents). Chemik, 3, 61-65. (in Polish).

2. Boodt de, M.F. (1993). Soil conditioning, a modern procedure for restoring physical soil degradation. Pedologie, 43, 157-195.

3. Dąbrowska, J., \& Lejcuś, K. (2012). Charakterystyka wybranych właściwości superabsorbentów (Characteristics of selected properties of superabsorbents). Infrastruktura i Ekologia terenów Wiejskich, 3(4), 1-10. (in Polish).

4. Helia, A.M., El-Amir, S., \& Shawky, M.E. (1992). Effects of Acryhope and Agnastore polymers on water regime and porosity in sandy soil. International Agrophysics, 6, 19-25.

5. Jabłońska-Ceglarek, R., \& Cholewiński, J. (1998). Ocena wpływu dodatku superabsorbentów do podłoża z substratu torfowego na plonowanie i wartość biologiczną papryki odm. Sirono (Assessment of the effect of the addition of superabsorbents to peat substrate on yields and biological value of pepper cv. 'Sirono'). Zeszyty Problemowe Postępów Nauk Rolniczych, 461, 209-216. (in Polish).

6. Junping, Z., An, L., \& Aiqin, W. (2006). Synthesis and characterization of multifunctional poly (acrylic acid-co-acrylamide) sodium humate superabsorbent composite. Reactive \& Functional Polymers, 66, 747-756.

7. Kilic, H., \& Yagbasanlar, T. (2010). The Effect of Drought Stress on Grain Yield, Yield Components and some Quality Traits of Durum Wheat (Triticum turgidum ssp. durum) Cultivars. Notulae Botanicae Horti Agrobotanici Cluj-Napoca. 38 (1), 164-170.

8. Kościk, B., \&'Kowalczyk-Juśko, A. (1998). Zastosowanie żelu Aqua Terra jako dodatku do podłoża w uprawie tytoniu papierosowego jasnego (Use of Aqua Terra gel as a substrate additive in the cultivation of light cigarette tobacco). Zeszyty Problemowe Postępów Nauk Rolniczych, 461, 227-238. (in Polish).

9. Lejcuś, K., Orzeszyna, H., Garlikowski, D., \& Pawłowski, A. (2006). Geocomposite with superabsorbent in landfill recultivation and slope protection. Environmental Engineering Proceedings of the 2nd National Congress on Environmental Engineering, 4-8 September 2005. Editors: Lucjan Pawłowski, Marzenna R. Dudzińska, Artur Pawłowski. Taylor and Francis. London.

10. Malisz, G., \& Kałędkowska, M. (1994). Krajowe superabsorbenty dla ogrodnictwa (Polish superabsorbents for horticulture). Hasło Ogrodnicze, 9, 6-7. (in Polish).

11. Mao, S., Islam, M.R., Xuzhang, X., Xuechao, Y., Xingbao, Z., \& Yuegao, H. (2011). Evaluation of watersaving superabsorbent polymer for corn (Zea mays L.) production in arid regions of Northern China. African Journal of Agricultural Research, 6(17), 4108-4115. 
12. Nowosielski, O. (1996). Supersorbenty obniżają koszty (Supersorbents reduce costs). Nowoczesne Rolnictwo, 4, 44-45. (in Polish).

13. Sady, W., \& Domagała, I. (1994). Ekogel MI może być przydatny do zakładania trawników (MI Ekogel can be useful for laying lawns). Ogrodnictwo, 1, 26-29. (in Polish). 